\title{
In vitro evaluation of cutaneous penetration of acyclovir from semisolid commercial formulations and relation with its effective antiviral concentration
}

\author{
Rafaela Martins Sponchiado*, Leticia Malgarim Cordenonsi, Nathalie Ribeiro Wingert, \\ Bibiana Verlindo de Araujo, Nadia Maria Volpato
}

Faculty of Pharmacy, Federal University of Rio Grande do Sul, Porto Alegre-RS, Brazil

\begin{abstract}
The evaluation of drug permeation/penetration of semisolid formulations into animal skin can be useful to supplement the pharmaceutical equivalence. This paper describes the in vitro assessment of acyclovir (ACV) into porcine skin from commercial formulations with etermination of drug concentration in different layers of cutaneous tissue to correlate with effective antiviral concentration in order to improve the equivalence decision. Studies were conducted using Franz cells and porcine skin. Selected pharmaceutical creams containing ACV had identical (reference and generic) and different (similar) excipients. A software program was employed for the simulation of antiviral effectiveness in the skin. Regarding ACV skin penetration, the first batch of the generic product showed a significant difference from reference and similar products, while in the second batch all products demonstrated equivalent drug penetration in the skin. Simulation studies suggest that formulations analysed exhibit a pharmacological effect even when in contact with Herpes simplex strains of high $\mathrm{IC}_{50}$ (inhibitory concentration required to reduce viral replication by $50 \%$ ). According to results, it can be assumed that the in vitro cutaneous permeation/penetration study does not supply sensitivity information regarding small alterations of ACV semisolid formulations due to the variability inherent to the method, although it can be relevant to pharmaceutical equivalence studies in the development of semisolid products.
\end{abstract}

Uniterms: Acyclovir/skin penetration/in vitro studies. Acyclovir/semisolid formulations. Acyclovir/ pharmaceutical equivalence.

\section{INTRODUCTION}

Acyclovir (2-amino-1,9-dihydro-9-((2hydroxyethoxy)methyl)-6H-purin-6-one) (ACV) (Figure 1 ) is a guanosine derivative drug with high specificity for herpesviruses. Due to its high efficacy against herpes simplex virus (HSV) and varicella-zoster virus, ACV has been the leading treatment for these pathologies until now (Field, Hodge, 2013). The action mechanism is based on competition with endogenous nucleosides for viral DNA incorporation, which disable DNA chain elongation and, therefore prevent viral replication (Barreca et al., 2003; Lupi, Silva, Pereira, 2000).

Regarding the topical dosage forms, currently several brands from different manufacturers can be found

\footnotetext{
*Correspondence: R.M. Sponchiado. Faculdade de Farmácia. Universidade Federal do Rio Grande do Sul - UFRGS. Av. Ipiranga, n.2752, 90610-000 - Porto Alegre - RS, Brazil. E-mail: rafasponchiado@hotmail.com
}<smiles>Nc1nc2c(ncn2COCO)c(=O)[nH]1</smiles>

FIGURE 1 - Chemical structure of ACV.

in the market, mainly as cream formulations. It is known that to obtain a better effect on skin virus affections, antiviral drugs must reach therapeutic concentrations in the basal cells of the epidermis, which are the earliest point of entry for virus propagation. Accordingly, penetration of an active pharmaceutical into the skin is a critical factor for successful treatment of oral herpes by ACV topical formulation (Hasler-Nguyen et al., 2009).

Implementation of in vitro methods to evaluate 
the performance of topical pharmaceutical formulations is very important, not only to predict drug permeation/ penetration into the skin, but also as a valuable tool to compare generic and reference products. Some authors also point out its significance to monitor variations among batches manufactured on an industrial scale (De Paula, Martin, Bentley 2008; Shah et al., 1991). Undoubtedly, studies regarding cutaneous penetration/ permeation are important to optimize and develop semisolid pharmaceutical formulations. They enable a better understanding of what happens to the drug after it is applied to the skin, the release from the pharmaceutical formulation, penetration and percutaneous absorption.

According to the World Health Organization (WHO, 2006), studies regarding in vitro cutaneous absorption are increasingly being submitted for registration of topical products. Several published papers compare in vivo and in vitro results, and studies following OECD (Organization of Economic Co-operation and Development) directives demonstrate that in vitro tests provide a good prediction of cutaneous absorption (Alberti et al., 2001; Gannu et al, 2010; Tsai et al., 2010).

Currently, a release study with Franz vertical diffusion cells (VDC) is the in vitro method most employed and accepted by international regulation guidelines due to its good reproducibility (Sartorelli et al., 2000; OECD, 2004). FDA (Food and Drug Administration, USA) recommends VDC employing synthetic membranes to evaluate scale-up and post-approval alteration in topical formulations (FDA, 1997). However, cutaneous permeation studies employing skin specimens in this diffusion bi-compartment model usually provide more variable results.

Therefore, the purpose of this paper was to verify whether in vitro determination of cutaneous permeation/ penetration of ACV from commercial formulations (reference $-\mathrm{R}$, generic $-\mathrm{G}$, and similar $-\mathrm{S}$ ) can indicate the maintenance of drug activity and product equivalence, relating the ACV concentration in different layers of cutaneous tissue to effective antiviral concentration. A bioanalytical method for drug quantification in skin layers (epidermis and dermis) of pig ears was validated for this purpose.

\section{MATERIAL AND METHODS}

Generic and similar 5\% ACV dermatologic creams were selected by analysing the composition of excipients from different brands found in the Brazilian market, compared to the reference product (Zovirax ${ }^{\circledR}$, GlaxoSmithKline). Table I presents the qualitative composition of chosen formulations according to excipient function or action within the formulation. Two medicines with similar formulations and one with a different composition were selected. $\mathrm{R}$ and $\mathrm{G}$ products present excipients with equivalent characteristics for instance, including propylene glycol, whose presence may promote drug permeation. In contrast, medicine $\mathrm{S}$ did not contain that inactive ingredient.

All reagents were analytical or HPLC grade. Ultrapure water was obtained by 3 UV Millipore ${ }^{\circledR}$ Derect-Q (Molsheim, France). Pig ears were acquired from the Ouro do Sul slaughterhouse (Harmonia, Brazil).

\section{Chromatographic system}

The analytical method was developed in a Shimadzu LC-10A system (Kyoto, Japan) equipped with an LC20AT pump, SPD-20AV UV-VIS variable wavelength detector (254 nm), DGU-20A5 degasser, CBM-20A controller system, and SIL-20A injection valve with 100 $\mu \mathrm{L}$ loop. Phenomenex C8 column (5 $\mu \mathrm{m}, 250 \mathrm{~mm} \times 4.6$ $\mathrm{mm}$ i.d.) and pre column C8 (4 x $3.0 \mathrm{~mm})$ were kept at $25^{\circ} \mathrm{C}$. The mobile phase consisted of water and methanol $(95: 5, \mathrm{v} / \mathrm{v})$ in isocratic mode, with $1 \mathrm{~mL} / \mathrm{min}$ flow and 50 $\mu \mathrm{L}$ of sample injection was used.

TABLE I - Qualitative composition of $5 \%$ ACV creams selected (water and ACV are elements present in all formulations and therefore not included in this table

\begin{tabular}{|c|c|c|c|c|c|}
\hline Product & Preservative & Emulsifier & $\begin{array}{c}\text { Lipophilic vehicle/ } \\
\text { Emollient }\end{array}$ & $\begin{array}{c}\text { Absorption } \\
\text { promoter }\end{array}$ & Others \\
\hline $\begin{array}{l}\text { Glaxo SmithKline } \\
\text { (Reference) }\end{array}$ & - & $\begin{array}{c}\text { Cetostearyl alcohol, } \\
\text { polaxamer } 407\end{array}$ & $\begin{array}{c}\text { Vaseline, liquid } \\
\text { paraffin. }\end{array}$ & Propylene glycol & Sodium lauril sulfate \\
\hline $\begin{array}{l}\text { Prati-Donaduzzi } \\
\text { (Generic) }\end{array}$ & $\begin{array}{l}\text { Propylparaben } \\
\text { Methylparaben }\end{array}$ & Cetostearyl alcohol & Liquid petrolatum & Propylene glycol & Sodium lauril sulfate \\
\hline
\end{tabular}




\section{Skin preparation}

Pig ears, obtained before the slaughter line scalding step, were initially washed with water. The central portion of the external side was excised and cut with a scalpel and moulded into a round shape to fit Franz cells, wrapped with PVC film and aluminium foil and kept under $-20{ }^{\circ} \mathrm{C}$ for up to 30 days.

\section{Acyclovir extraction procedure}

In order to validate the extraction procedure, skin segments without blood vessels or scars were cut in 1.5 $\mathrm{cm}$ diameter circles (equivalent to the Franz cells contact area). For validation requirements, dermis and epidermis separation was performed with a scalpel after immersion into water at $60^{\circ} \mathrm{C}$ for 45 seconds. Dermis was additionally sectioned into small parts and, only then transferred to separate tubes. Dermis and epidermis were spiked with ACV aqueous solution and kept still for 2 hours. The cycle of ACV extraction from skin layers occurred by addition of $4 \mathrm{~mL}$ of water in the tubes and sonication for over $40 \mathrm{~min}$

\section{Bioanalytical method validation}

Bioanalytical method validation followed national and international guidelines (ANVISA, 2012; ICH, 2005). Method specificity was evaluated by comparing chromatograms from samples with and without ACV after skin extraction.

Standard curves were analysed on three different days with drug concentrations from 0.5 to $25 \mu \mathrm{g} / \mathrm{mL}$. Samples were diluted with biological matrices in the same proportion as the extraction procedure $(1.5 \mathrm{~cm}$ diameter skin per $8 \mathrm{~mL}$ of water). Results were submitted to linear regression analysis through minimum square method and ANOVA (analysis of variance) statistical evaluation. Limits of detection and quantification were estimated according to standard curve and confirmed through experiments. Intercept significance was also verified.

Method precision was assessed by ACV recovery from the main skin layers. After separation, dermis and epidermis were spiked with $50 \mu \mathrm{L}$ of ACV solution at three known concentration levels (low, median, and high). The final concentration corresponded to $0.5,12.5$, and $25 \mu \mathrm{g} / \mathrm{mL}$; each level had $\mathrm{n}=6$ for both skin layers.

\section{In vitro skin penetration studies}

Skin samples were thawed at room temperature and mounted in Franz diffusion cells (Hanson Research,
Chatsworth, USA) with stratum corneum (SC) facing donor compartment and dermis in contact with receptor compartment. The diffusion area of Franz cells was 1.77 $\mathrm{cm}^{2}$, and the receptor container was filled with $7 \mathrm{~mL}$ phosphate buffer, $\mathrm{pH}$ 7.4. Pig skin was kept in contact with the receptor solution at $32^{\circ} \mathrm{C}\left( \pm 1^{\circ} \mathrm{C}\right)$ for up to 8 hours and aliquots of $1 \mathrm{~mL}$ were collected at predetermined times $(1,4,6$, and $8 \mathrm{~h})$ to analyse ACV permeation through the skin. The same volume of receptor fluid withdrawn was replaced to keep it constant. After 8 hours, skin was detached from the Franz cell and excess formulation carefully removed. Without water immersion, scalpel and scissor were applied to separate skin layers, epidermis and dermis, which were weighed and extraction proceeded as described previously.

Results are presented as $\mu \mathrm{g}$ of ACV per mg of tissue; all data $(\mathrm{n}=15)$ and mean values \pm standard deviation $(\mathrm{SD})$ were computed. Data were analysed by one-way ANOVA in order to compare the three pharmaceutical formulations. Tukey test was applied to significant results $(\alpha=0.05)$.

\section{Pharmacodynamic study - simulation of ACV antiviral effect on skin layers}

Scientific literature provides different in vitro and in vivo values for inhibition of $\mathrm{HSV}-1$ replication. Values of $\mathrm{IC}_{50}$ (inhibitory concentration for $50 \%$ of viral replication) found for plaque number reduction assay using Vero cells presented divergent patterns, which, for the purpose of this study, were classified as low, median, and high potency, evidencing the characteristic of drugvirus interaction (species-specific) (Cavalli et al., 2009; Drugbank databese; Gong et al., 2004; Jalón et al., 2003; Suzuki, Okuda, Shiraki, 2006).

Comparison between expected effects at concentration ranges found for $\mathrm{ACV}$ in the in vitro permeation assay from $\mathrm{R}, \mathrm{G}$, and $\mathrm{S}$ formulations was performed by means of Scientist ${ }^{\circledR}$ software program. employing a model of inhibitory effect for ACV and values of $\mathrm{IC}_{50}$ described in the literature for different viral strains (Table II). The model is described by equation 1 , where $E$ is the expected effect, $E_{0}$ the effect on absence of drug inhibition, $\mathrm{I}_{\max }$ is the maximum inhibition promoted by $\mathrm{ACV}$ (inhibition of replication), $\mathrm{C}$ is ACV concentration evaluable in the tissue to produce an effect (in this situation $\mu \mathrm{g} / \mathrm{g}$ was employed $)$, and $\mathrm{IC}_{50}(\mu \mathrm{g} / \mathrm{mL})$ is the concentration necessary to promote half of the maximum inhibitory effect (Gabrielsson, Weiner, 2006).

$$
E=E_{0}-\frac{\left(I_{\max } C\right)}{\left(I C_{50}+C\right)} \quad \text { Equation } 1
$$


To obtain a dose-response curve, low, median, and high $\operatorname{IC}_{50}(0.049,0.265$, and $0.850 \mu \mathrm{g} / \mathrm{mL}$, respectively) values from scientific literature were used.

TABLE II - ACV IC ${ }_{50}$ values found in scientific literature for distinct HSV-1 strains in plaque number reduction assay.

\begin{tabular}{lcc}
\hline ACV IC $_{\mathbf{5 0}}$ & $\mathbf{I C}_{\mathbf{5 0}} \mathbf{A C V}(\boldsymbol{\mu g} / \mathbf{m L})^{\mathbf{1}}$ & Reference \\
\hline $1.3 \mu \mathrm{M}$ & $0.293^{(\mathrm{M})}$ & Drug Bank \\
$0.16 \mu \mathrm{M}$ & $0.036^{(\mathrm{L})}$ & Cavalli et al, 2009 \\
$0.85 \mu \mathrm{g} / \mathrm{mL}$ & $0.850^{(\mathrm{H})}$ & $\begin{array}{c}\text { Suzuki, Okuda and } \\
\text { Shiraki 2006 }\end{array}$ \\
$1.06 \mu \mathrm{M}$ & & Jalón et al, 2003 \\
$0.28 \mu \mathrm{M}$ & $0.238^{(\mathrm{M})}$ & Gong et al, 2004 \\
\hline
\end{tabular}

$(\mathrm{H})$ : high value $\mathrm{IC}_{50} ;(\mathrm{M})$ median value of $\mathrm{IC}_{50} ;(\mathrm{L})$ low value $\mathrm{IC}_{50} .1$ : data were standardized in $\mu \mathrm{g} / \mathrm{mL}$

\section{RESULTS AND DISCUSSION}

\section{Method validation}

Analytical conditions allowed an adequate peak signal of ACV in the presence of biological matrix, although with small interferences. According to official regulation guidelines, the presence of a chromatographic response relative to blank sample along with analyte must be lower than $20 \%$ of the limit of quantification (LoQ). On that basis, at the lower quantification concentration of ACV $(0.5 \mu \mathrm{g} / \mathrm{mL})$, the higher signal from biological matrices corresponded to $2.95 \%$ and $11.75 \%$ of the drug peak signal in epidermis and dermis, respectively (Figure 2).

The method developed presented an appropriate linearity at $0.5-25 \mu \mathrm{g} / \mathrm{mL}$ concentration range from 3 days analysis. The mean standard curve equation $\mathrm{y}=$ $153656 x+33034$ had a determination coefficient $\left(\mathrm{r}^{2}\right)$ equal
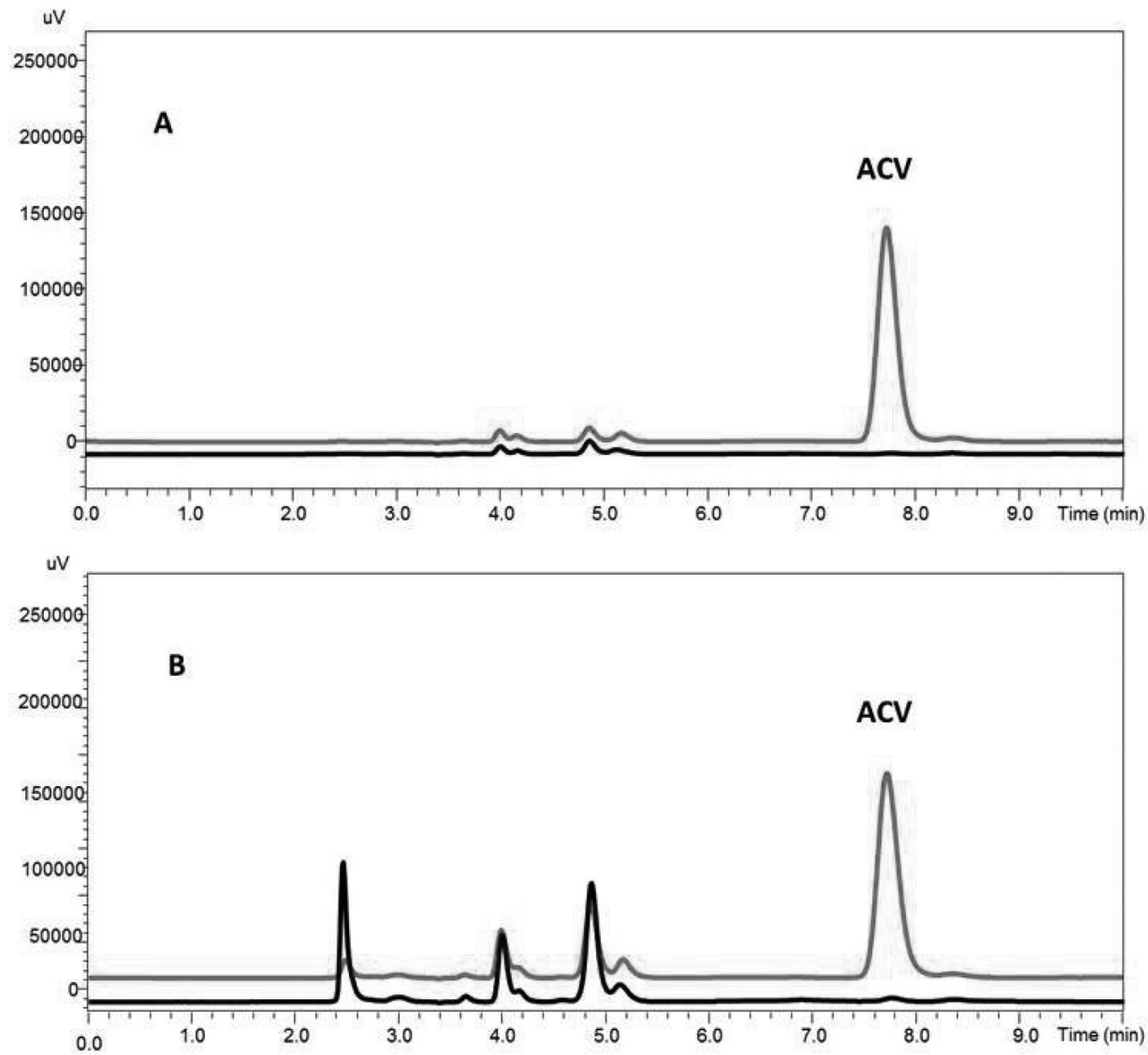

FIGURE 2 - Specificity of chromatographic method for the analysis of ACV in skin layers. A) Epidermis; B) Dermis. Black line: blank sample (biological matrix); grey line: ACV solution at $12.5 \mathrm{mg} / \mathrm{mL}$, eluting at $7.8 \mathrm{~min}$ retention time. 
to 0.9999 . According to data obtained from ANOVA it is possible to ensure significant linear regression (Fcalculated $=37278.2>$ Fcritical $=8.53)$ without deviation from linearity $($ Fcalculated $=0.35<$ Fcritical $=4.20)$. Limits of detection and quantification were 0.11 and $0.36 \mu \mathrm{g} / \mathrm{mL}$, respectively. Experimentally, five injections at $0.3,0.4$, and $0.5 \mu \mathrm{g} / \mathrm{mL}$ presented an RSD of $0.77 \%, 1.26 \%$, and 2.20 $\%$, demonstrating that the proposed LoQ was precise and sensitive. During the study, every chromatographic run was performed with a new standard curve, which furnished an average slope of $(n=18)$. The $\mathrm{p}$-value for the intercept was always greater than 0.05 .

Method precision and accuracy were evaluated in terms of ACV recovery from biological matrices. Table III presents data obtained for ACV recovery from skin layers (epidermis and dermis), and RSD for intra-day repeatability and intermediate precision at each concentration level of ACV added to matrices. Average data recovered were $92.74 \%$ for epidermis and $90.65 \%$ for dermis, values which are in agreement with those recommended by scientific guidelines. Regarding precision assessment, RSD ranged from $4.36 \%$ to $6.77 \%$ which is considered acceptable for a bioanalytical method $(<15 \%)$ and also indicates suitability of the extraction process and quantification of $\mathrm{ACV}$ in the main skin layers.

\section{Comparative cutaneous penetration study}

A validated bioanalytical method was applied to the quantification of ACV in both skin layers (dermis and epidermis) after formulations were applied. ACV penetration was evaluated from three commercial creams ( $R, G$, and $S$ ) in two different batches, corresponding to six samples. Results regarding accumulated amount of ACV in skin layers for R, G, and S samples in a cutaneous permeation study are shown in Figures 3 and 4. Evaluating Figure 3, it can be concluded that overall, a higher concentration of ACV is detected in epidermis than in dermis, a condition that is ideal for ACV pharmacological effect against herpes virus. The amount of drug accumulated in epidermis and dermis for $\mathrm{R}$ and $\mathrm{S}$ products was substantially lower than that obtained with $\mathrm{G}$, according to statistical evaluation. The main difference between the formulations is the presence of propylene glycol in the $\mathrm{R}$ and $\mathrm{G}$ products. This excipient may have more than one function in a pharmaceutical formulation. Besides being a carrier, it can act as permeation promoter in amounts usually applied for dermatological products (Trottet et al., 2004). The action mechanism proposed for propylene glycol suggests that its input in SC increases penetrant solubility, with a consequent increment of the flow through skin tissue (Moser et al., 2001; Williams,

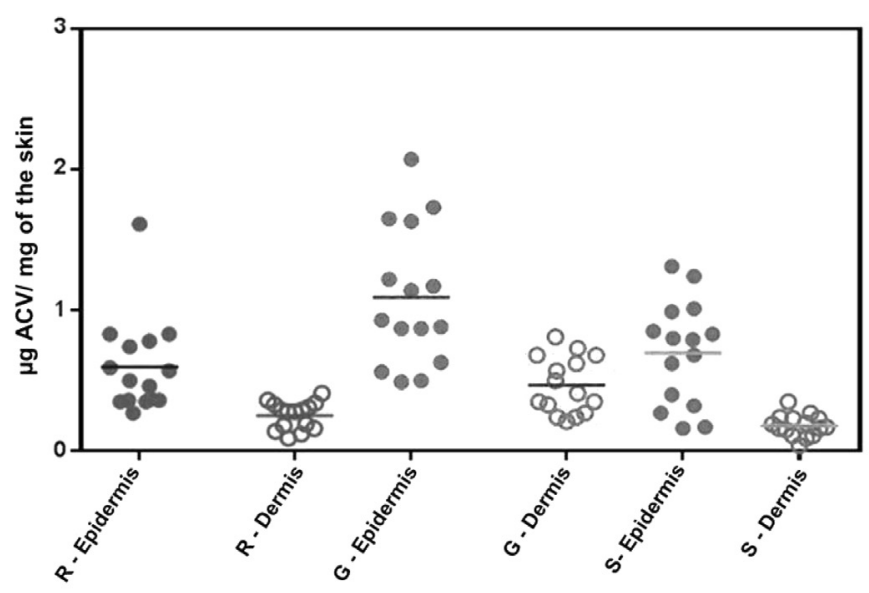

FIGURE 3 - Retained amount of ACV in porcine skin layers regarding the first batch of reference $(\mathrm{R})$, generic $(\mathrm{G})$, and similar (S) products, expressed in $\mu \mathrm{g} / \mathrm{mg}$. Each symbol corresponds to an obtained value and the horizontal bar represents the mean concentration $(n=15)$.

TABLE III - Accuracy and precision of the bioanalytical method for ACV quantification

\begin{tabular}{llccccc}
\hline \multirow{2}{*}{ Skin Layers } & Level & \multicolumn{2}{c}{ Day 1 } & \multicolumn{2}{c}{ Day 2 } \\
\cline { 3 - 7 } & concentration \pm SD & $\begin{array}{c}\text { RSD (\%) } \\
\text { intra-day }\end{array}$ & $\begin{array}{c}\text { Observed } \\
\text { concentration } \pm \text { SD }\end{array}$ & $\begin{array}{c}\text { RSD (\%) } \\
\text { intra-day }\end{array}$ & $\begin{array}{c}\text { RSD (\%) } \\
\text { inter-day }\end{array}$ \\
\hline \multirow{2}{*}{ Epidermis } & Low & $0.42 \pm 0.02$ & 4.92 & $0.43 \pm 0.02$ & 4.65 & 4.36 \\
& Medium & $11.82 \pm 0.9$ & 7.54 & $12.83 \pm 0.05$ & 0.36 & 6.41 \\
& High & $22.41 \pm 1.50$ & 6.72 & $24.46 \pm 0.24$ & 0.99 & 6.32 \\
\hline \multirow{2}{*}{ Dermis } & Low & $0.47 \pm 0.01$ & 3.27 & $0.48 \pm 0.04$ & 7.94 & 5.6 \\
& Medium & $10.95 \pm 1.2$ & 10.33 & $11.35 \pm 0.16$ & 1.38 & 6.77 \\
& High & $22.15 \pm 2.0$ & 9.05 & $21.96 \pm 0.70$ & 3.17 & 6.10 \\
\hline
\end{tabular}


Barry, 2012). The manufacturers do not inform the amount of propylene glycol, but it is possible that one of those mechanisms occurred, explaining the higher concentration of ACV from the first batch of $\mathrm{G}$ product found in skin layers.

Another difference that can be considered is the presence of sodium lauryl sulfate (SLS - anionic surfactant) in $\mathrm{R}$ and $\mathrm{G}$ formulations. The action mechanism of SLS has not yet been completely explained. However, it is well known that it interacts with keratin and intracellular lipids, and also promotes changes in the helix conformation of SC proteins, facilitating drug absorption (Nokhodchi et al., 2003; Rafeiro, 2013). Therefore, this characteristic will differ between formulations, according to the concentration of SLS.

It should be highlighted that physical and physicochemical characteristics of the drug and further elements in the formulation, as well as in the manufacturing process, may lead to variation of bioavailability that, for the generic product, may compromise bioequivalence and, therefore inter-changeability. Product R presented higher viscosity than products $\mathrm{G}$ and $\mathrm{S}$, which supplied very similar rheological profiles (data not shown).

On the other hand, statistical evaluation of the second batch (Figure 4) has indicated the absence of a significant difference ( $p>0.05$ ) between formulations $R$, $\mathrm{G}$, and S. Dissimilar results regarding batches 1 and 2 for $\mathrm{G}$ product may indicate the poor homogeneity between manufactured batches. Semi solid pharmaceutical dosage forms are complex formulations and their physicochemical

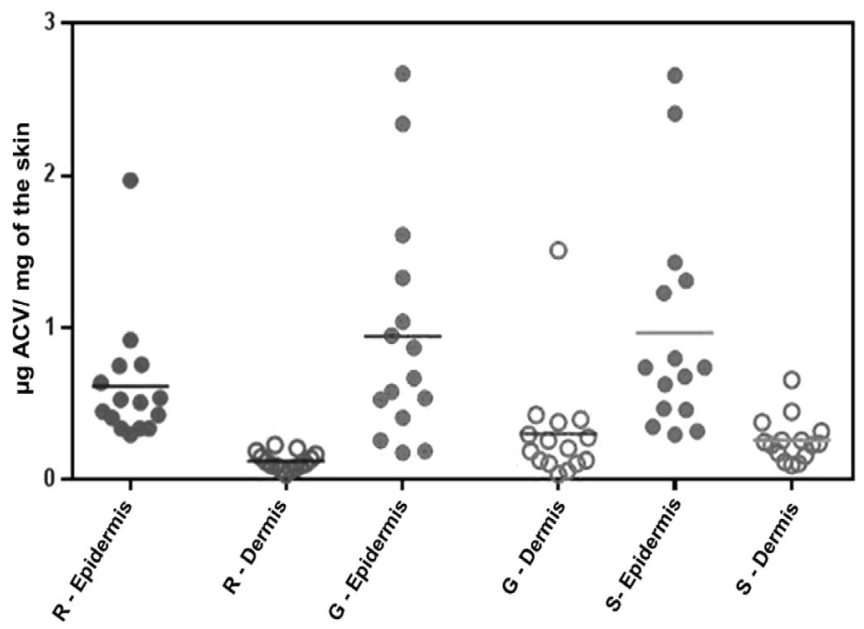

FIGURE 4 - Retained amount of ACV in porcine skin layers regarding the second batch of reference $(R)$, generic $(G)$, and similar (S) products, expressed in $\mu \mathrm{g} / \mathrm{mg}$. Each symbol corresponds to an obtained value and the horizontal bar represents the mean concentration $(n=15)$. release and penetration properties involve several factors. Initial separation of the system into two phases and the step of adding an active component are critical points in the semisolid fabrication process. Any change in one of these processes may alter the formulation properties, and the permeation and release characteristics of the active ingredient (OECD, 2004).

A statistical analysis performed between batches (for the same brand) pointed out the homogeneity of ACV retained in the epidermis for formulation $\mathrm{R}$, but a different retention in the dermis. This also occurred for product $\mathrm{G}$ (epidermis: $p=0.539$ and dermis: $p=0.009$ ), while for product $\mathrm{S}$, the retained amount in epidermis $(\mathrm{p}=0.206)$ was considered equal comparing the two lots, as well as in dermis $(\mathrm{p}=0.06)$.

As for the sum of ACV amounts retained in both layers, statistical tests showed no significant difference between the batches of pharmaceutical products (Figure 5). Statistical analysis of overall assessments (comparison between two lots of three products) revealed a significant difference only between $\mathrm{R}$ product from the second batch and $\mathrm{G}$ product from the first batch.

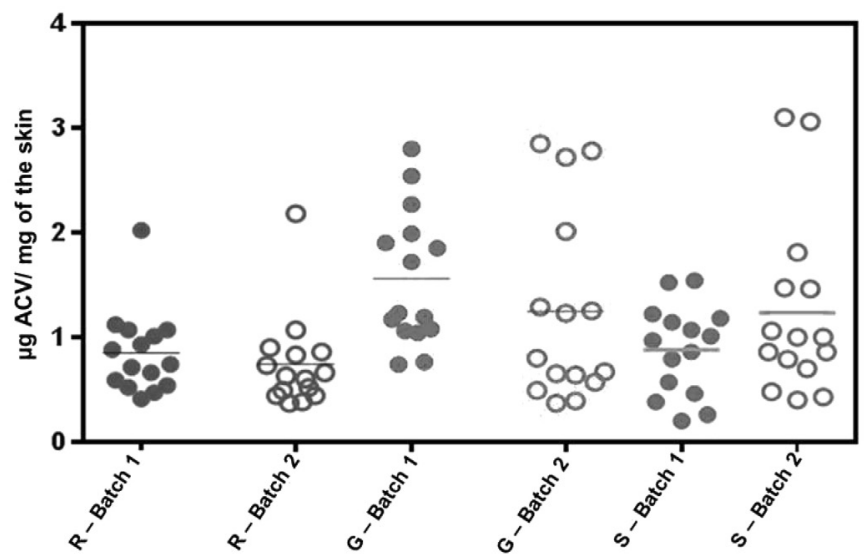

FIGURE 5 - Retained amount of ACV from reference (R), generic $(\mathrm{G})$, and similar (S) products with the drug concentrations found in skin layers (epidermis + dermis) for the two batches analysed.

Whenever cutaneous permeation/penetration was evaluated $(8 \mathrm{~h}), \mathrm{ACV}$ was not detected in the receptor solution. According to Hasler-Nguyen et al. (2009) ACV presents a hydrophobic region which can interact with the hydrophobic structures in SC, affecting drug permeation. On the other hands, dermis presents hydrophilic characteristics thereby representing a barrier against free transition of substances with high partition coefficient and limited water solubility. These results confirm the release of ACV only in skin tissue (topically), which is the location required for effective treatment of 
TABLE IV - Medium and Standard deviation (SD) from 15 determinations regarding the penetration study in porcine skin for the analyzed batch

\begin{tabular}{|c|c|c|c|c|}
\hline Commercial Creams & Batch & Skin Layers* & Medium $(\mu \mathrm{g} / \mathrm{mg})^{* *}$ & $\begin{array}{c}\text { Standard deviation - SD } \\
(\mu \mathrm{g} / \mathrm{mg})\end{array}$ \\
\hline \multirow{4}{*}{$\mathrm{R}$} & \multirow{2}{*}{1} & $\mathrm{E}$ & 0.60 & 0.34 \\
\hline & & $\mathrm{D}$ & 0.25 & 0.10 \\
\hline & \multirow{2}{*}{2} & $\mathrm{E}$ & 0.62 & 0.42 \\
\hline & & $\mathrm{D}$ & 0.12 & 0.06 \\
\hline \multirow{4}{*}{ G } & \multirow{2}{*}{1} & $\mathrm{E}$ & 1.09 & 0.49 \\
\hline & & $\mathrm{D}$ & 0.47 & 0.20 \\
\hline & \multirow{2}{*}{2} & $\mathrm{E}$ & 0.94 & 0.76 \\
\hline & & $\mathrm{D}$ & 0.30 & 0.36 \\
\hline \multirow{4}{*}{ S } & \multirow{2}{*}{1} & $E$ & 0.70 & 0.37 \\
\hline & & $\mathrm{D}$ & 0.18 & 0.08 \\
\hline & \multirow{2}{*}{2} & $\mathrm{E}$ & 0.97 & 0.73 \\
\hline & & $\mathrm{D}$ & 0.26 & 0.15 \\
\hline
\end{tabular}

${ }^{*} \mathrm{E}=$ epidermis; $\mathrm{D}=$ dermis; ${ }^{* *} \mathrm{n}=15$

cutaneous herpetic viruses, without achieving systemic circulation and causing adverse effects.

It is worth noting that high values obtained for standard deviation during experiments performed can be explained by inherent variability by the inherent variability of studies with characteristics from cutaneous tissue (pig skin) - interindividual differences, growth, sex, and skin thickness (Godin, Touitou, 2007). Those values might be related to skin layer weight which was fairly uniform: $22.2 \pm 6.7 \mathrm{mg}$ for epidermis and $92.0 \pm 23.7 \mathrm{mg}$ for dermis over ninety measurements (Table IV).

Recently, the national drug regulation agency of Brazil (ANVISA, 2014) declared that eleven topical brands of ACV were interchangeable, including the products employed in this study. In the USA, the FDA determines the optimal bioequivalence approach for each proposed generic topical formulation on a caseby-case basis. The approach may be pharmacokinetics, pharmacodynamics, clinical or in vitro considering drug mechanism and site of action, complexity of reference formulation, and feasibility and sensitivity of each approach. For ACV ointment 5\%, generic and reference products must contain the same amounts of active and inactive ingredients and, as in the USA, the reference is considerably less complex than a cream, consisting of drug suspended in a polyethylene glycol (PEG) base. The in vitro release approach (with inert membrane) can be used for equivalence purposes. Particle size, viscosity, morphic form and PEG molecular weight distribution are also required. No cutaneous permeation is mentioned in the document. The products employed in this study are creams and ACV release through synthetic membrane was not evaluated (Davit, 2013).

\section{Simulation of viral inhibitory effect on skin layers}

When a pharmacodynamics study is performed, a direct relationship is expected between exposition and effect, and thus higher drug exposition will result in an increased viral inhibition response.

Results show that concentrations achieved for ACV in total skin, for all pharmaceutical specialities studied and two batches analysed would present an antiviral effect that is much superior to $50 \%$ of inhibition. Therefore, studied products may be considered capable of providing $\mathrm{ACV}$ in cutaneous tissue in amounts that surpass $\mathrm{IC}_{50}$ viral replication, even when there are strains with high $\mathrm{IC}_{50}$ values. Throughout the drug concentration range found in the skin tissue, the effect calculated according to Equation 1 was greater than $98 \%$. Therefore, medicines evaluable in the Brazilian market are believed to present an adequate therapeutic effect against herpes virus, and are capable of shortening the viral cycle and reducing the main symptoms (rash, burn, and redness).

\section{CONCLUSION}

The proposed analytical methodology is sensitive, accurate and precise for the detection and quantification of $\mathrm{ACV}$ in skin layers of pig ears and therefore, in accordance 
with national and international standards. According to the studies performed the different composition with absence of propylene glycol in $\mathrm{S}$ product is not evidenced by means of an in vitro cutaneous penetration test and it can be assumed that the method possesses a limited capability to distinguish some differences in formulations due to its inherent variability. The results obtained for the ACV amounts in the skin are in accordance with the interchangeability between products proposed by the national regulatory agency for medicines. Nevertheless, it may be important to evaluate drug skin absorption from semisolid formulations during the development phase, as well as to predict drug concentration in skin layers (dermis and epidermis).

\section{REFERENCES}

AGÊNCIA NACIONAL DE VIGILÂNCIA SANITÁRIA. ANVISA. Resolução RDC 58, de 10 de outubro de 2014. Dispõe sobre as medidas a serem adotadas junto à Anvisa pelos titulares de registro de medicamentos para a intercambialidade de medicamentos similares com o medicamento de referência. Diário Oficial da União, Brasília, Poder executivo, 2014.

AGÊNCIA NACIONAL DE VIGILÂNCIA SANITÁRIA. ANVISA. Resolução RE nº 27, de 17 de maio de 2012. Diário Oficial da União, Brasília, 22 maio 2012.

ALBERTI, I.; KALIA, Y. N.; NAIK, A.; BONNY, J. D.; GUY, R. H. In vivo assessment of enhanced topical delivery of terbinafine to human stratum corneum. J. Control Rel., v.71, n.3, p.319-327, 2001.

BARRECA, M.L.; CHIMIRRI A., CLERCQ E.D., LUCA L.D., MONFORTE A.M.; MONFORTE P.; RAO A., ZAPPALÀ M. Anti-HIV agents: design and discovery of new potent RT inhibitors. Farmaco, v.58, n.3, p.259-263, 2003.

CAVALLI, R., DONALISIO, M., CIVRA, A., FERRUTI, P., RANUCCI, E., TROTTA, F., LEMBO, D. Enhanced antiviral activity of Acyclovir loaded into $\beta$-cyclodextrinpoly(4-cryloylmorpholine) conjugate nanoparticles. $J$. Control Rel., v.137, n.2, p.116-122, 2009.

DAVIT, B.M. Regulatory approaches for generic drugs: BE of topical drug products. In: PQRI workshop on the evaluation of new and generic topical drug products - current challenges in bioequivalence, quality and novel assessment technologies. Rockville, MD, 2013.
DE PAULA, D., MARTIN, C.A., BENTLEY, M.V.L.B. Development and validation of HPLC method for imiquimod determination in skin penetration studies. Biomed. Chromatogr., v.22, n.12, p.1416-1423, 2008.

DRUGBANK. Database. Acyclovir. Available at: $<\mathrm{http}: / \mathrm{http}: / /$ www.drugbank.ca/drugs/DB00787> . Accessed at: 10 Oct. 2014.

FIELD, H. J.; HODGE, R. A. V. Recent developments in antiherpesvirus drugs. Br. Med. Bull., v.106, n.1, p.213-249, 2013.

FOOD AND DRUG ADMINISTRATION. FDA. CENTER FOR DRUG EVALUATION AND RESEARCH. CDER. Scale-Up and postapproval changes: chemistry, manufacturing, and Controls; in vitro release testing and in vivo bioequivalence documentation. Rockville, MD: FDA, Sep. 1997.

GABRIELSSON, J.; WEINER, D. Pharmacokinetic \& pharmacodynamic data analysis: concepts and applications. 4. ed. Stockholm: Apotekarsocieteten, 2006.

GANNU, R.; PALEM, C.R.; YAMSANI, V.V.; YAMSANI, S.K.; YAMSANI, M.R. Enhanced bioavailability of lacidipine via microemulsion based transdermal gels: formulation optimization, ex vivo and in vivo characterization. Int. $J$. Pharm., v.388, n.1, p.231-241, 2010.

GODIN, B.; TOUITOU, E. Transdermal skin delivery: predictions for humans from in vivo, ex vivo and animal models. Adv. Drug Deliv. Rev., v.59, n.11, p.1152-1161, 2007.

GONG, Y.; RAJ, K.M.; LUSCOMBE, C.A.; GADAWSKI, I.; TAM, T.; CHU, J.; GIBSON, D; CARLSON, D; SACKS, S.L. The synergistic effects of betulin with acyclovir against herpes simplex viroses. Antivir. Res., v.64, n.2, p.127-130, 2004.

HASLER-NGUYEN, N.; SHELTON, D.; PONARD, G.; BADER, M.; SCHAFFRIK, M.; MALLEFET, P. Evaluation of the in vitro skin permeation of antiviral drugs from penciclovir $1 \%$ cream and acyclovir $5 \%$ cream used to treat herpes simplex virus infection. BMC Dermatol., v.9, n.1, p.1-10, 2009. 
INTERNATIONAL CONFERENCE ON HARMONISATION. ICH. Harmonized tripartite guideline. Validation of analytical procedures: text and methodology Q2 (R1). Geneva, SW: ICH, 2005. v.1.

JALÓN, E.G.; BLANCO-PRÍETO, M.J.; YGARTUA, P.; SANTOYO, S. Increased efficacy of acyclovir-loaded microparticles against herpes simplex virus type 1 in cell culture. Eur. J. Pharm. Biopharm., v.56, n.2, p.183-187, 2003.

LUPI, O.; DA SILVA, A.G; PEREIRA Jr, A.C (Org). Herpes: clínica, diagnóstico e tratamento. Rio de Janeiro: Medsi, 2000 .

MOSER, K.; KRIWET, K.; NAIK, A.; KALIA, Y.N.; GUY, R. H. Passive skin penetration enhancement and its quantification in vitro. Eur. J. Pharm. Biopharm., v.52, n.2, p.103-112, 2001.

NOKHODCHI, A.; SHOKRI, J.; DASHBOLAGHI, A.; HASSAN-ZADEH, D.; GHAFOURIAN, T.; BARZEGARJALALI, M. The enhancement effect of surfactants on the penetration of lorazepam through rat skin. Int. J. Pharm., v. 250, p. 359-369, 2003.

ORGANIZATION FOR ECONOMIC COOPERATION AND DEVELOPMENT. OECD. Skin absorption: in vitro method, test guideline No 428. Guidelines for the testing of chemicals. Paris: OECD, v.1, n.4, p.1-8, 2004.

RAFEIRO, D.F.B. Novas estratégias de promoção de permeação transdérmica. 2013. Dissertação (Mestrado Integrado em Ciências Farmacêuticas) - Universidade Lusófona, Lisboa, 2013.

SARTORELLI, P.; ANDERSEN, H.R.; ANGERER, J.; CORISH, J.; DREXLER, H.; GÖEN, T.; GRIFFIN, P.; HOTCHKISS, S.A.M.; LARESE, F.; MONTOMOLI, L.; PERKINS, J.; SCHMELZ, M.; VAN DE SANDT, J.; WILLIAMS, F. Percutaneous penetration studies for risk assessment. Environ. Toxicol. Pharm., v.8, n.2, p.133-152, 2000.
SHAH, V.P., FLYNN, G.L., GUY, R.H., MAIBACH, H.I., SCHAEFER, H., SKELLY, J.P., WESTER, R. In vivo percutaneous penetration/absorption. Int. J. Pharm, v.74, n.8, p.1-8, 1991.

SUZUKI, M.; OKUDA, T.; SHIRAKI, K. Synergistic antiviral activity of acyclovir and vidarabine against herpes simplex virus types 1 and 2 and varicella-zoster vírus. Antivir. Res., v.72, p.157-161, 2006.

TROTTET, L., MERLY, C., MIRZA, M., HADGRAFT, J., DAVIS, A.F. Effect of finite doses of propylene glycol on enhancement of in vitro percutaneous permeation of loperamide hydrochloride. Int. J. Pharm, v.274, n.1, p.213219, 2004.

TSAI, Y.H.; LEE, K.F.; HUANG, Y.B.; HUANG, C.T.; WU, P.C. In vitro permeation and in vivo whitening effect of topical hesperetin microemulsion delivery system. Int. J. Pharm., v.388, n.1, p.257-262, 2010.

WILLIAMS, A.C.; BARRY, B.W. Penetration enhancers. $A d v$. Drug Deliv. Rev., v.64. p.128-137, 2012.

WORLD HEALTH ORGANISATION. WHO. KIELHORN, J.; MELCHING-KOLLMUSS, S.; MANGELSDORF, I. Dermal Absorption. Environmental Health Criteria. Draft February 2006. Geneva, SW: WHO/IPCS, 2006. Available in: <http://www.inchem.org/documents/ehc/ehc/ehc235. pdf $>$. Accessed in: 8 mar. 2014.

Received for publication on $31^{\text {st }}$ August 2015 Accepted for publication on $17^{\text {th }}$ May 2016 
